\title{
The Quality of Health Services in Tawaeli Health Center, Tawaeli District, Palu City
}

\author{
Dian Angraeni ${ }^{1}$, H. Abu Tjaiyya ${ }^{2}$, Muhammad Akhyar ${ }^{3}$, Abd. Muhaimin Tayeb ${ }^{4}$ \\ 1.2 Universitas Tadulako, Palu \\ ${ }^{3,4}$ Balai Besar Pelatihan Kesehatan Makassar \\ E-mail: angraenidian13@ gmail.com
}

(Received: March-2018; Reviewed: April-2018; Accepted: July-2018;

Avalaibel Online: September-2018; Published: September-2018)

This is an open access article distributed under the Creative Commons Attribution License

CC-BY-NC-4.0 @2018 by author (https://creativecommons.org/licenses/by-nc/4.0/)

\begin{abstract}
Effective public services carried out by governments or corporations can strengthen democracy and human rights, promote economic prosperity, reduce poverty, improve environmental protection, be wise in the use of natural resources, deepen trust in government and public administration. The purpose of this study was to determine how the quality of health services at the Tawaeli Health Center, Tawaeli District, North Palu. This type of research is qualitative research that is a study used to investigate, describe and explain a phenomenon or problem. To find out the quality of health services in the Tawaeli Health Center according to Zeithaml-Parasuraman-Berry there are four indicators used namely tangible, reliability, responsiveness, assurance, and empathy. There are 8 informants in this study with accidental technique, which is the technique of determining samples based on chance. The results in this study indicate that the Health Services at the Tawaeli Health Center in the District of Tawaeli in Palu City are seen from several aspects that are still not good, the first is tangible, responsiveness is also still lacking. However, seen from the aspects of reliability, assurance, and empathy, it was considered good.
\end{abstract}

Keywords: Tangible; reliability; responsiveness; assurance and empathy.

\section{INTRODUCTION}

Public service is an activity or a series of activities in the framework of fulfilling service needs in accordance with statutory regulations for every citizen and resident of goods, services, and / or administrative services provided by public service providers, public service providers or organizers are each organizing institution countries, corporations, independent institutions formed under the law for public service activities, and other legal entities formed solely for public service activities.

The public service law (Law of the Republic of Indonesia Number 25 of 2009) is a law governing the principles of good governance which is the effectiveness of the functions of government itself. Effective public services carried out by governments or corporations can 
strengthen democracy and human rights, promote economic prosperity, reduce poverty, improve environmental protection, be wise in the use of natural resources, deepen trust in government and public administration (Farida, Wagiyanto, Bustamin, \& Salam, 2017; Nawir, Maulana, Nuryamin, \& Husain, 2018; Niswaty, Juniati, Darwis, Salam, \& Arhas, 2019; Syamsiar, Saggaf, Salam, \& Ihsan, 2018).

Puskesmas is a functional organization that organizes comprehensive, integrated, equitable, acceptable and affordable health efforts by the community, with active community participation and uses the results of the development of appropriate science and technology, with costs that can be borne by the government and the community (Dobransky, 2009; Lega, 2007; Merrill, Bakken, Rockoff, Gebbie, \& Carley, 2007; Taichman et al., 2009; Timpka, Bång, Delbanco, \& Walker, 2007). The health effort is carried out by focusing on services for the wider community in order to achieve optimal health levels, without ignoring the quality of services to individuals. Puskesmas is a health technical implementation unit under the supervision of the District / City Health Office. In general, they must provide preventive, promotive, curative to rehabilitative services either through Individual Health Efforts (UKP) or Public Health Efforts (UKM). Puskesmas can provide inpatient services in addition to outpatient services. To provide good services, of course, it is always endeavored to improve the quality of services in order to achieve optimal health status for the whole community (Dobransky, 2009; Lega, 2007; Merrill et al., 2007; Taichman et al., 2009; Timpka et al., 2007).

The goal of health development as a national commitment can be seen in article 3 (Law Number 36 of 2009 concerning Health), namely: Health development aims to increase awareness, willingness, and ability to live healthy for everyone so as to realize the highest level of public health, as an investment for development of human resources that are socially and economically productive.

Puskesmas is a functional organization that organizes comprehensive, integrated, equitable, acceptable and affordable health efforts by the community, with active community participation and uses the results of the development of appropriate science and technology, with costs that can be borne by the government and the community (Elyazar, Hay, \& Baird, 2011; "Free Communication (Oral) Presentations," 2015; Ghuman \& Singh, 2013; Nugroho Joshua, Agus Swastika, \& Windha Daniaty, 2017; Shibata et al., 2015). The health effort is carried out by focusing on services for the wider community in order to achieve optimal health levels, without ignoring the quality of services to individuals. Puskesmas is a health technical implementation unit under the supervision of the District / City Health Office. In general, they must provide preventive, promotive, curative to rehabilitative services either through Individual Health Efforts (UKP) or Public Health Efforts (UKM). Puskesmas can provide inpatient services in addition to outpatient services. To provide good services, of course, it is always endeavored to improve the quality of services in order to achieve optimal health status for the whole community (Komljenovic, Loiselle, \& Kumral, 2017; Lluch, 2011; Pallas, Curry, Bashyal, Berman, \& Bradley, 2012; Rojatz \& Forster, 2017; Weed et al., 2016).

Palu City is one of the provincial capitals in Indonesia which is right on the Equator (Pratomo \& Rudiarto, 2013; Rusydi, Efendi, Sandra, \& Rahmawati, 2018; Samad, Tawil, Kafrawi, \& Kafiah, 2018). Tawaeli Puskesmas is one of the Puskesmas located in Tawaeli Subdistrict and is an alternative chosen by the community as a place of health services for community members, primarily emphasizing the health of patients who come for medical treatment directly even though in a gradual manner. In other words, the attention and sincerity of health services is very meaningful for the healing and recovery of patients' health both from the upper class, middle class, especially in the weak economic group. With the Tawaeli Health Center, health services to the community can be easier and faster so that the quality or quality of 
health services to the community can improve and can meet the demands of service for the community.

Tawaeli Health Center always tries to serve well in all care needs including curative services (treatment), preventive (preventive efforts), promotive (health improvement) and rehabilitation (health recovery) in the hope that patients who receive health services feel satisfied. However, in activities health services at the Puskesmas in Tawaeli Subdistrict still have shortcomings such as the lack of chairs in the waiting room, the lack of security in the parking lot and the slow service at the drug collection counter, triggering patient dissatisfaction with the services provided. This is contrary to the theory put forward by Zeithhaml, Parasuraman \& Berry in terms of service quality with indicators namely Tangibles (Physical evidence) which include adequate facilities and infrastructure, the availability of safe parking spaces, and the tidiness of officers and responsiveness including the ability to provide services in a manner fast, precise and responsive to the wishes of the patient.

\section{METHOD}

This type of research is a qualitative descriptive study. The types of data used are primary data and secondary data, which consists of documents, archival reports and scientific books. Data collection techniques used are observation, interviews, documentation and triangulation. Data analysis consists of data collection, data condensation, data presentation and drawing conclusions.

\section{RESULT AND DISCUSSION}

The measure of success in presenting quality health services is the level of satisfaction of users of services being served. The level of satisfaction of service users can be achieved if there is a match between what is expected by service users with the reality obtained, in the sense that if the needs, desires and expectations of service users can be met, then they will feel satisfied and well served. The service system must have service standards that are used as benchmarks in terms of service delivery.

\section{Tangible}

Tangible is related to the availability of Puskesmas facilities, as a support for the comfort of patients or recipients of services which include several things, namely: completeness of facilities, completeness of telecommunications facilities, availability of adequate, clean and tidy seats, completeness of information places regarding service flow, security. Based on the research results Tangibles aspects are still not good due to lack of waiting rooms and lack of security in the parking lot.

\section{Reliability}

This indicator is to measure how the services provided by the Tawaeli Community Health Center to patients in providing services in accordance with what is promised such as the accuracy / accuracy of diagnosis, and the expertise and accuracy of the medical team in providing services to patients. Based on the results of the research aspects of reliability are in the category quite well. 


\section{Responsiveness}

Responsiveness is the ability of employees or nurses to provide services quickly and responsively. The indicators of this dimension consist of employees / nurses responding quickly, employees / nurses immediately provide solutions to community complaints, officers always provide information related to patient problems. However, based on the results of the study, the responsiveness aspect is also still not good due to frequent delays in service at the drug collection counter.

\section{Assurance}

Guarantee or assurance is very important to be owned by a Puskesmas or Puskesmas, be it a guarantee of ability, friendliness and courtesy in carrying out tasks in order to provide a sense of security and ensure and increase public confidence in Puskesmas Tawaeli. Based on the research results, the assurance aspect is in the good category

\section{Empathy}

Empathy firm but attentive attitude in providing services to consumers with indicators: employees / nurses are diligent in serving the community, employees / nurses are patient in serving the community, Employees / nurses are sincere in providing services, employees / nurses always pay attention to patients, staff / nurses always ask the patient's progress and complaints. Based on the results of the study, empathy aspects are in the good category.

\section{Discussion}

\section{Tangible}

Minister of Administrative Reform Decree No. 63 of 2003, the principles of service include environmental comfort must be orderly, orderly, provided a comfortable waiting room, clean, beautiful and healthy environment, equipped with service support facilities, such as parking, toilets, places of worship and others- other. Crosby's opinion (Nasution \& Setiawan, 2007) states that what is meant by quality is conformance to requirements, that is, in accordance with what is required or standardized. Waiting room standards are seen in terms of size and size, cleanliness and comfort, as well as fentilation or lighting / illumination levels.

\section{Reliability}

This indicator is to measure how the services provided by the Tawaeli Community Health Center to patients in providing services in accordance with what is promised such as the accuracy / accuracy of diagnosis, and the expertise and accuracy of the medical team in providing services to patients. Based on the results of the research aspects of reliability are in the category quite well.

\section{Responsiveness}

Responsiveness is the ability of employees or nurses to provide services quickly and responsively. Responsiveness can foster a positive perception of the quality of services provided. This includes failures or delays in service delivery, the service provider seeks to 
correct or minimize the loss that the patient receives immediately. This dimension emphasizes the attention and speed of the employees involved to respond to patient requests, questions and complaints.

\section{Assurance}

Assurance is the ability, friendliness and courtesy in the implementation of services as well as convincing public trust with indicators: Employees / nurses should create a sense of security, employee / nurse guarantees the absence of payments and fees other than those required, patient communication and medical personnel running smoothly, friendly and polite employees / nurses

\section{Empathy}

The quality of service seen from the empathy aspect is to give sincere and individual or personal attention to the community by efforts to understand the wishes of the community. The empathy aspect always calls for complaints of the patient's problems, the officer's response to the patient's complaints and how the officer can recognize the patient well. Empathic service is in need of personal touch / feeling.

\section{CONCLUSION}

Based on the results of research conducted, that the Quality of Public Services in Building Permit in the Office of Investment and Integrated Services of One Door in the City of Palu, has not been effective. Viewed from several aspects, among others: Tangible, Reliability, Rersponsivinees, Assurance, Empathy. There are two aspects of maximum service quality, namely the Responsiveness aspect (response), namely that the apparatus in accepting the community who take care of permits is good enough, the information conveyed by the officers can already be understood by the public. But the speed in arranging building permits is not in line with expectations, because people have to wait months for the issuance of building permits that have been taken care of. And empathic aspects, that is, there is no discrimination in the service of building permits. Therefore, there are still some of the five dimensions of service quality that need to be improved, so that the quality of services provided to the public can be maximized.

\section{REFERENCES}

Dobransky, K. (2009). The good, the bad, and the severely mentally ill: Official and informal labels as organizational resources in community mental health services. Social Science \& Medicine, 69(5), 722-728. https://doi.org/https://doi.org/10.1016/j.socscimed.2009.06.038

Elyazar, I. R. F., Hay, S. I., \& Baird, J. K. (2011). Chapter 2 - Malaria Distribution, Prevalence, Drug Resistance and Control in Indonesia (D. Rollinson \& S. I. B. T.-A. in P. Hay, Ed.). https://doi.org/https://doi.org/10.1016/B978-0-12-385897-9.00002-1

Farida, U., Wagiyanto, E., Bustamin, M., \& Salam, R. (2017). Analysis of Empowerment Program that was Implemented in Mamuju Regency East Sulawesi Indonesia. 2nd 
International Conference on Education, Science, and Technology (ICEST 2017). Atlantis Press.

Free Communication (Oral) Presentations. (2015). International Journal of Gynecology \& Obstetrics, 131, E72-E313. https://doi.org/https://doi.org/10.1016/S0020-7292(15)300035

Ghuman, B. S., \& Singh, R. (2013). Decentralization and delivery of public services in Asia. $\begin{array}{llll}\text { Policy and } & \text { Society, }\end{array}$ https://doi.org/https://doi.org/10.1016/j.polsoc.2013.02.001

Komljenovic, D., Loiselle, G., \& Kumral, M. (2017). Organization: A new focus on mine safety improvement in a complex operational and business environment. International Journal of Mining Science and Technology, 27(4), 617-625. https://doi.org/https://doi.org/10.1016/j.ijmst.2017.05.006

Lega, F. (2007). Organisational design for health integrated delivery systems: Theory and $\begin{array}{llll}\text { practice. Health } & \text { Policy, } & \text { 258-279. }\end{array}$ https://doi.org/https://doi.org/10.1016/j.healthpol.2006.06.006

Lluch, M. (2011). Healthcare professionals' organisational barriers to health information technologies-A literature review. International Journal of Medical Informatics, 80(12), 849-862. https://doi.org/https://doi.org/10.1016/j.ijmedinf.2011.09.005

Merrill, J., Bakken, S., Rockoff, M., Gebbie, K., \& Carley, K. M. (2007). Description of a method to support public health information management: Organizational network analysis. Journal of Biomedical Informatics, 40(4), 422-428. https://doi.org/https://doi.org/10.1016/j.jbi.2006.09.004

Nawir, R., Maulana, R., Nuryamin, M., \& Husain, T. (2018). Implementation Program of Poor Rice Copyright.

Niswaty, R., Juniati, F., Darwis, M., Salam, R., \& Arhas, S. H. (2019). The Effectiveness of Leadership Functions Implementation in The Makassar Departement of Manpower. JPBM (Jurnal Pendidikan Bisnis dan Manajemen), 5(1), 1-10.

Nugroho Joshua, J. W., Agus Swastika, I. P., \& Windha Daniaty, T. O. (2017). E-Government Integration through Implementation of web-based GIS on Community Health monitoring in Jembrana Regency, Bali. Procedia Computer Science, 124, 552-559. https://doi.org/https://doi.org/10.1016/j.procs.2017.12.189

Pallas, S. W., Curry, L., Bashyal, C., Berman, P., \& Bradley, E. H. (2012). Improving health service delivery organisational performance in health systems: a taxonomy of strategy areas and conceptual framework for strategy selection. International Health, 4(1), 20-29. https://doi.org/https://doi.org/10.1016/j.inhe.2011.09.002

Rojatz, D., \& Forster, R. (2017). Self-help organisations as patient representatives in health care and policy decision-making. Health Policy, 121(10), 1047-1052. https://doi.org/https://doi.org/10.1016/j.healthpol.2017.08.012

Shibata, T., Wilson, J. L., Watson, L. M., Nikitin, I. V, Ansariadi, La Ane, R., \& Maidin, A. (2015). Life in a landfill slum, children's health, and the Millennium Development Goals. Science of The Total Environment, 536, 408-418. https://doi.org/https://doi.org/10.1016/j.scitotenv.2015.05.137

Syamsiar, S., Saggaf, M. S., Salam, R., \& Ihsan, S. R. (2018). Implementation Of Supervision 
On Office Of Community Empowerment And Makassar City Village.

Taichman, D. B., McGoon, M. D., Harhay, M. O., Archer-Chicko, C., Sager, J. S., Murugappan, M., ... Gallop, R. (2009). Wide Variation in Clinicians' Assessment of New York Heart Association/World Health Organization Functional Class in Patients With Pulmonary Arterial Hypertension. Mayo Clinic Proceedings, 84(7), 586-592. https://doi.org/https://doi.org/10.4065/84.7.586

Timpka, T., Bång, M., Delbanco, T., \& Walker, J. (2007). Information infrastructure for interorganizational mental health services: An actor network theory analysis of psychiatric rehabilitation. Journal of Biomedical Informatics, 40(4), 429-437. https://doi.org/https://doi.org/10.1016/j.jbi.2006.11.001

Weed, V., Finkelman, M., Wawrzyniak, K., Kulich, R., Myrta, E., \& DiBenedetto, D. (2016). (194) The use of the World Health Organization Disability Assessment Schedule (WHODAS 2.0) in a chronic pain population: the importance of functional assessment in the context of opioid risk evaluations. The Journal of Pain, 17(4, Supplement), S24. https://doi.org/https://doi.org/10.1016/j.jpain.2016.01.097 
100

Pinisi Discretion Review

Volume 2, Issue 1, September, 2018. Pages 93-100 